\title{
Cyclosporine A Induces MicroRNAs Controlling Innate Immunity during Renal Bacterial Infection
}

\author{
Malick Sadio $^{\mathrm{a}}$ Emilie Tourneur $^{\mathrm{a}}$ Marcelle Bens $^{\mathrm{a}} \quad$ Jean-Michel Goujon ${ }^{\mathrm{b}}$ \\ Alain Vandewalle $^{\mathrm{a}}$ Cécilia Chassin $^{\mathrm{a}}$ \\ ${ }^{a}$ ATIP-Avenir Team Chassin, University Paris Diderot, Sorbonne Paris Cité, CRI, UMR 1149, Inserm, Paris, and \\ bService d'Anatomie et Cytologie Pathologiques, Centre Hospitalier Universitaire de Poitiers, Université de Poitiers, \\ Poitiers, France
}

\section{Keywords}

Collecting duct · Escherichia coli $\cdot$ Toll-like receptor $4 \cdot$ Let-7i · Kidney

\begin{abstract}
Urinary tract infections (UTIs) mainly due to uropathogenic Escherichia coli (UPEC) are one of the most frequent complications in kidney-transplanted patients, causing significant morbidity. However, the mechanisms underlying UTI in renal grafts remain poorly understood. Here, we analysed the effects of the potent immunosuppressive agent cyclosporine A ( CsA) on the activation of collecting duct cells that represent a preferential site of adhesion and translocation for UPEC. CSA induced the inhibition of lipopolysaccharideinduced activation of collecting duct cells due to the downregulation of the expression of TLR4 via the microRNA Let-7i. Using an experimental model of ascending UTI, we showed that the pretreatment of mice with CsA prior to infection induced a marked fall in cytokine production by collecting duct cells, neutrophil recruitment, and a dramatic rise of bacterial load, but not in infected TLR4-defective mice kidneys. This effect was also observed in CsA-treated infected kidneys, where the expression of Let-7i was increased. Treatment with a synthetic Let-7i mimic reproduced the effects of
\end{abstract}

CsA. Conversely, pretreatment with an anti-Let-7i antagonised the effects of CsA and rescued the innate immune response of collecting duct cells against UPEC. Thus, the utilisation of an anti-Let-7i during kidney transplantation may protect CsA-treated patients from ascending bacterial infection.

(c) 2017 S. Karger AG, Basel

\section{Introduction}

Despite the improvement of surgical procedures and immunosuppressive therapies, urinary tract infections (UTIs) still represent the most frequent bacterial infections in kidney-transplanted recipients, and are responsible of morbidity and renal graft dysfunction [1-3]. Uropathogenic Escherichia coli (UPEC) is the most common cause of UTIs in the general population as well as in kidney-transplanted patients [1, 4-6].

UPEC may ascend along the urinary tract and colonise the kidneys [7]. Members of the family of Toll-like receptors (TLRs), particularly TLR4, which senses lipopolysaccharide (LPS) from gram-negative bacteria, expressed in renal parenchymal cells and bone marrow-derived cells, play key roles in the initiation of the innate response for

\section{KARGER}

(C) 2017 S. Karger AG, Basel

E-Mail karger@karger.com

www.karger.com/jin
Dr. Cécilia Chassin

Centre de Recherche sur l'Inflammation (CRI), UMR 1149

UFR de Médecine Xavier Bichat

BP 416, 16 rue Henri Huchard, FR-75018 Paris Cedex 18 (France)

E-Mail cecilia.chassin@gmail.com 
the defense of the host and efficient renal bacterial clearance [8-10]. Using experimental models of ascending UTIs, we have shown that UPEC preferentially adheres to the parenchymal medullary collecting duct (MCD), which in turn develops TLR4-dependent and independent signaling pathways leading to the production of cytokines and the recruitment of polymorphonuclear neutrophils (PMNs) to the site of inflammation $[11,12]$.

Long-term immunosuppressive therapy in the context of transplantation increases the susceptibility to infection. However, the mechanisms by which immunosuppressive agents may favour renal bacterial infection still remain poorly understood. The calcineurin inhibitor cyclosporine A (CsA) is one the most potent immunosuppressive agents used in the prevention of renal graft rejection. However, CsA can be nephrotoxic and causes chronic interstitial fibrosis $[1,2,13]$. High concentrations of CsA trigger the apoptosis of renal tubule cells [14]. Interestingly, CsA was also shown to impair cytokine-induced matrix-metalloproteinase- 9 associated with an inhibition of the IL- $1 \beta$-induced activation of the transcription factor $\mathrm{NF}-\kappa \mathrm{B}$ and mitogen-activated protein (MAP) kinase c-Jun N-terminal kinase (JNK) in rat mesangial cells [15]. Moreover, we previously showed that CsA impairs nucleotide binding oligomerisation domain (Nod1)-mediated innate antibacterial renal defenses in mice and human transplant recipients $[16,17]$. These findings raised the possibility that CsA can impair the activation of MCD cells caused by LPS and UPEC, and thereby favour the intrarenal colonisation of UPEC.

Recent advances in genomics, sequencing technologies, and bioinformatics have generated an explosion of genetic information, highlighting the importance of understanding mechanisms involved in gene expression and regulation. Gene expression can be regulated by different mechanisms, such as through transcription factors, alternative splicing, or epigenetics and gene silencing by small RNAs, including microRNAs (miRs). miRs are highly conserved non-coding small single-stranded RNA molecules that have emerged as master regulators of gene expression in plants and animals, from nematodes to arthropods and humans, and even viruses. miRs have been shown to be major actors in the tuning of a broad range of developmental, cell differentiation, and cell maintenance functions. miRs have been especially implicated in the regulation of inflammatory processes and some of them, such as miR-146a, miR-155, the miR-17-92 cluster, miR-21, miR-125b, miR-203, or the let-7 family, have been shown to regulate innate immune signaling [18-21]. However, the association between $\mathrm{miR}$ dysregulation and the pathogenesis of inflammatory kidney diseases is poorly defined.

We therefore analysed the effects of CsA on TLR4mediated cell activation in immortalised renal collecting duct cells, mpkCCD $\mathrm{cl}_{4}$, and in primary cultures of MCD dissected from the kidneys of wild-type $\mathrm{C} 3 \mathrm{H} / \mathrm{HeN}\left(L p s^{n}\right)$ mice and Trl4-inactivated C3H/HeJ $\left(L p s^{d}\right)$ mice. The involvement of miRs was also assessed and the consequence of long-term administration of CsA on the renal innate response and renal bacterial burden were also analysed. The present findings establish that CsA alters Tlr4 gene expression in an miR-dependent manner and impairs TLR4-mediated cell activation in MCD cells, favouring bacterial infections.

\section{Materials and Methods}

\section{Cell Culture and Incubations}

$\mathrm{mpkCCD}_{\mathrm{cl} 4}$ cells and RAW 264.7 cells were cultured as described $[11,22,23]$. Escherichia coli K12 D31m4 LPS (List Biological Laboratories) was used for the stimulations. The purity of the LPS preparation was confirmed by the complete absence of stimulating activity on peritoneal macrophages isolated from Tlr4-deficient mice. The absence of endotoxin in the CsA solution was checked with the chromogenic QCL-1000 limulus amebocyte lysate assay (Lonza) as described previously [24]. CsA was preincubated for $18 \mathrm{~h}$ prior to LPS stimulation. For miRNA silencing, an $\mathrm{miR}$ inhibitor against Dicer and Drosha was used together with a Cy3-labelled negative control miR inhibitor (Ambion) at a final concentration of $100 \mathrm{nM}$ as previously described [24]. The same protocol was used for the transfection of anti-miR (anti-Let-7i inhibitor; Ambion) and mature microRNA mimics (mmu-Let-7i miRIDIAN mimic, Dharmacon RNAi Technologies).

\section{Bacteria}

We used the HT7 UPEC strain isolated from the urine of a woman with acute pyelonephritis. HT7 expresses papGII encoding the PagG subunit (allelic variant II) of P fimbriae frequently expressed in pyelonephritic E. coli, but lacks the virulent factors $c n f 1$, hly, and sat encoding necrotising and vacuolating cytotoxins.

\section{miRNA PCR Array}

$\mathrm{mpkCCD}_{\mathrm{cl} 4}$ cells were or were not incubated with CsA, and miRs were isolated using the RNeasy Micro Kit (Qiagen) according to the manufacturer's instructions. Samples were then sent to Qiagen for the performance of a miScript miRNA PCR array.

\section{Ethics Statement}

All animal experiments were approved by and conducted in accordance with the guidelines of the French Agricultural Office and in compliance with the French and European regulations on Animal Welfare (Service de la Protection et Santé Animale; Approval No. 75-687, revised 2008) and with Public Health Service recommendations. All efforts were made to minimise the suffering of the mice. 
Microdissection and Culture of MCDs

Experiments were also carried out on primary cultures of isolated MCDs dissected from the kidneys of 9- to 13-week-old C $3 \mathrm{H} /$ $\mathrm{HeJ} L p s^{d}$ mice, C3H/HeOuJ Lps ${ }^{n}$ mice, or wild-type C57BL/6 mice as described previously [11]. Pools of isolated MCD (8-12 fragments) were seeded onto collagen-coated, $1-\mu \mathrm{m}$-pore-sized Transwell permeable filters and grown to confluence as described already [25]. Experiments were carried out 2 weeks after seeding, using confluent cells with a transepithelial electrical resistance of $\geq 4,000 \Omega \cdot \mathrm{cm}^{2}$. All experiments were carried out in accordance with French legislation governing animal studies.

\section{Renal Retrograde Infection in Mice}

Adult female wild-type mice (8-10 weeks old, supplied by the Centre d'Elevage Janvier, Le Genest-Saint-Isle, France), from the $\mathrm{C} 3 \mathrm{H} / \mathrm{HeJ} L p s^{d}, \mathrm{C} 3 \mathrm{H} / \mathrm{HeOuJ} L p s^{n}$, or C57BL/6 genetic background were used. The mice were infected with the UPEC strain HT7 $\left(10^{8}\right.$ bacteria in $50 \mathrm{~mL}$ OF sterile PBS) introduced via the transurethral route into the bladder as PREVIOUSLY described [11]. A total of $100 \mathrm{~mL}$ of CsA ( $5 \mathrm{mg} / \mathrm{kg}$; Neoral, Novartis), or its vehicle (castor oil) were administered subcutaneously to mice for 5 days before the inoculation of UPEC. Injections of anti-miR (anti-Let-7i inhibitor, Ambion) or mature miR mimics (mmu-let-7i miRIDIAN mimic, Dharmacon RNAi Technologies) were performed once before the inoculation of bacteria using in vivo-jetPEI ${ }^{\circledR}$ (Polyplus transfection) according to the manufacturer's instructions. Bacterial loads (CFU) in the kidneys were determined $24 \mathrm{~h}$ after infection by plating.

\section{Histological and Immunohistochemical Studies}

Kidneys were fixed in Dubosq-Brazil solution, rinsed in PBS, embedded in paraffin, and stained with haematoxylin-eosin. The degree of inflammatory changes was assessed using a semiquantitative graded scale: 0 , no abnormality; 1 , mild lesions affecting $<25 \%$ of kidney samples; 2 , moderate lesions affecting $25-50 \%$ of kidney samples; 3 , diffuse lesions affecting $75 \%$ of kidney samples.

\section{Real-Time PCR and Reverse Transcription PCR}

TotalRNA from mousekidneys, mpkCCD $_{\mathrm{cl} 4}, \mathrm{MCD}$, RAW264.7, and BMM was purified with RNA NOW (Ozyme) and reverse transcribed using Moloney Murine Leukemia Virus reverse transcriptase $\left(200 \mathrm{U} / \mu \mathrm{L}\right.$, Invitrogen) for $60 \mathrm{~min}$ at $42^{\circ} \mathrm{C}$ in the presence of dNTP and oligo dT. The mouse Tlr4, Mip-2, Let-7i, siRNA Dicer, siDrosha, GAPDH, and Sno (PrimePCR ${ }^{\mathrm{TM}}$ SYBR $^{\circledR}$ Green Assay, Bio-Rad) cDNA was subjected to quantitative real-time PCR using the SYBR ${ }^{\circledR}$ Green method. Analyses were performed with a CFX96 real-time PCR detection system (Bio-Rad). Each sample was amplified in duplicate, and normalised versus the endogenous control. Results were calculated using the $2^{-\Delta \Delta C_{T}}$ method, and presented as the fold induction of the target gene transcript under stimulated versus unstimulated conditions.

\section{Immunoblot and Endotoxin Quantification}

Immunoblotting was performed as recently described [11]. Antibodies against TLR4 (rabbit polyclonal, Santa Cruz Biotechnology), total and phosphorylate ERK, JNK, NF- $\mathrm{BB}, \mathrm{p} 38$ (mouse monoclonal, Cell Signaling Technology), and $\beta$-actin (N-terminal domain; Sigma-Aldrich, Taufkirchen, Germany) were used in combination with peroxidase-labelled goat-anti-mouse or goat-anti-rabbit secondary antibodies (Jackson ImmunoResearch).

\section{ELISA}

Cxcl1 and $\mathrm{Cxcl} 2$ secretion in cell supernatants was then determined using ELISA kits (R\&D Systems) according to the manufacturer's instructions. For in vivo Cxcl1 and $\mathrm{Cxcl} 2$ measurements, kidneys from $L p s^{n}, L p s^{d}$, and wild-type mice infected with the UPEC strain HT7 isolates were homogenised in $1 \mathrm{~mL}$ of PBS and kept at $-80^{\circ} \mathrm{C}$ until used. Tissue samples were then thawed and assayed to measure the levels of $\mathrm{Cxcl} 1$ and $\mathrm{Cxcl} 2$ production. Results were standardised to the amount of protein detected for each sample using the Bio-Rad protein assay with BSA as the standard. Myeloperoxidase (MPO) activity was measured using the HyCult Biotechnology ELISA kit.

\section{Statistical Analysis}

Results are expressed as means $\pm \mathrm{SE}$, and are representative of at least 3 independent experiments for each of the experimental conditions tested. Differences were analysed with the unpaired Student $t$ test compared to the control. $p<0.05$ was considered significant.

\section{Results}

\section{CsA Selectively Impairs TLR4 Expression and LPS-Induced Cellular Activation in Renal Epithelial Collecting Duct Cells}

Renal MCD cells are the first cells in contact with UPEC during ascendant bacterial infection and initiate the inflammatory response mainly in a TLR4-dependent signaling pathway [11]. To check whether CsA has a specific effect on epithelial cells, we performed experiments on a highly differentiated cell line of MDC cells $\left(\mathrm{mpkCCD}_{\mathrm{cl} 4}\right)$, as well as primary cultures of MCD cells microdissected from the kidneys of wild-type mice, versus bone marrow-derived immune cells (macrophage-like RAW 264.7 cell line and freshly isolated bone marrow macrophages; BMMs). Confluent mpkCCD $\mathrm{cl}_{4}$ cells, RAW 264.7 cells, primary cultures of MCD, and BMMs

Fig. 1. CsA decreases cellular activation in renal collecting duct cells. a Variation in the levels of Tlr4 mRNAs measured by quantitative real-time PCR in confluent cultures of $\mathrm{mpkCCD}_{\mathrm{cl} 4}, \mathrm{MCD}$, RAW 264.7, and BMM cells incubated with various concentrations of CsA for $18 \mathrm{~h}$ compared to untreated controls. b Immunoblot analysis of TLR4 proteins and the corresponding $\beta$-actin in $\mathrm{mpkCCD}_{\mathrm{cl} 4}$ cells incubated with or without various concentrations of CsA for $18 \mathrm{~h}$. c Representative immunoblot showing the effect of CsA at $10^{-8} \mathrm{M}$ on the phosphorylation (p) of p65, ERK, and JNK proteins from LPS-treated $\mathrm{mpkCCD}_{\mathrm{cl} 4}$ cells. $\mathbf{d}$ CXCL1 (upper line) and CXCL2 (lower line) production measured by ELISA in wild-type mpkCCD ${ }_{\mathrm{cl} 4}$, primary cultured MCD, RAW 264.7, and BMM cells incubated with various concentrations of CsA for $18 \mathrm{~h}$, then with or without $10 \mathrm{ng} / \mathrm{mL}$ of LPS. Values are presented as the mean \pm SE compared to the control. $* p<0.05,{ }^{* * *} p<0.001$.

(For figure see next page.) 


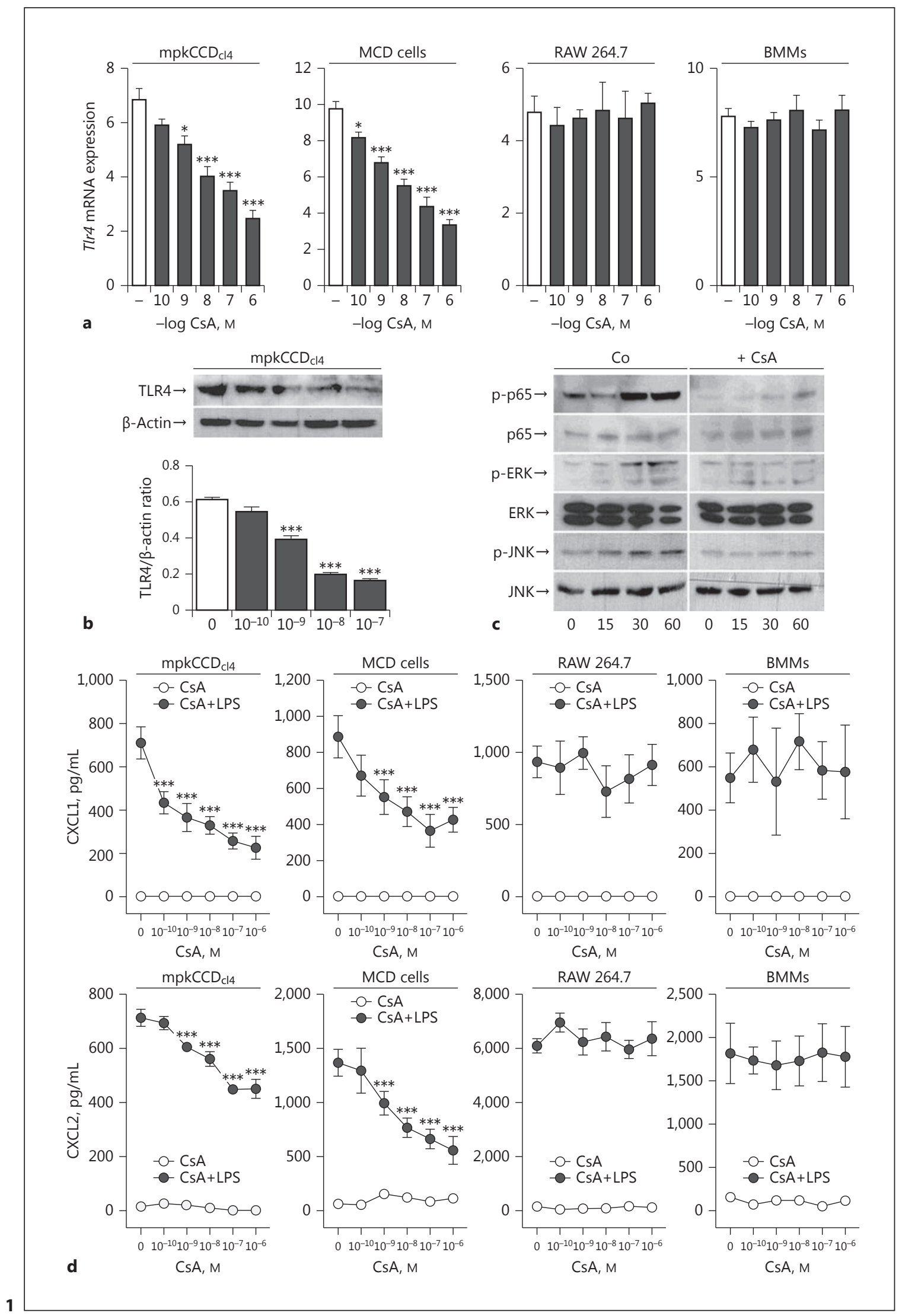




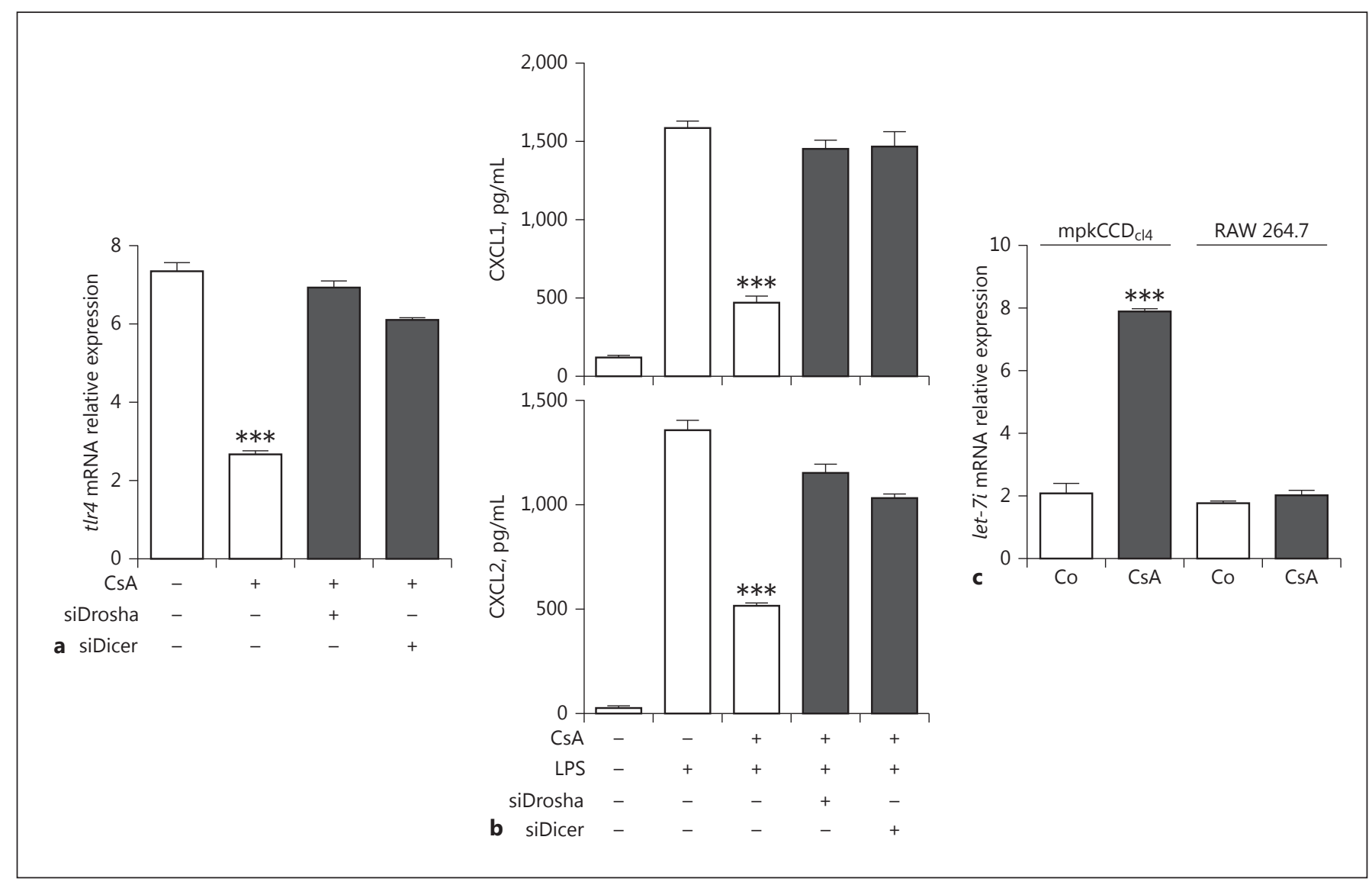

Fig. 2. CsA induces miR, modulating TLR4 expression, and LPSinduced cellular activation. a Relative expression of Tlr4 mRNA in mpkCCD $_{\mathrm{cl} 4}$ cells transfected or not with a siRNA against Drosha or Dicer, then treated or not with CsA $\left(10^{-8} \mathrm{M}\right)$ for $18 \mathrm{~h}$. b CXCL1 and CXCL2 production measured by ELISA in the supernatant of mpkCCD $_{\mathrm{cl} 4}$ cells transfected or not with a siRNA against Drosha

were incubated with different concentrations of CsA for $18 \mathrm{~h}$ at $37^{\circ} \mathrm{C}$. We carefully checked that these concentrations did not affect cell viability with an MTT assay $24 \mathrm{~h}$ after incubation with CsA (online suppl. Fig. 1a; see www.karger.com/doi/10.1159/000480248 for all online suppl. material). We then analysed the expression of Tlr4 mRNA and the results showed that CsA $\left(10^{-10}\right.$ to $\left.10^{-7} \mathrm{M}\right)$ significantly decreased the expression of $\mathrm{Tlr} 4 \mathrm{mRNA}$ in a dose-dependent manner in mpkCCD $\mathrm{cl}_{4}$ cells and primary cultures of MCD cells (Fig. 1a), with a $50 \%$ inhibition for $10^{-8} \mathrm{M}$ CsA. However, CsA had no effect on Tlr4 mRNA expression, neither in RAW 264.7 cells nor in BMMs (Fig. 1a). We then tested whether the downregulation of Tlr4 mRNA in renal epithelial cells caused by CsA was specific by checking the expression of other Tlrs under the same experimental conditions. Our results or Dicer, then treated or not with CsA and stimulated with LPS for 6 h. c Quantitative RT-PCR expression analysis of miRNA Let-7i in mpkCCD $\mathrm{cl}_{4}$ cells treated (CsA) or not (Co) with CsA $\left(10^{-8} \mathrm{M}\right.$ for $18 \mathrm{~h})$. Values are presented as the mean $\pm \mathrm{SE}$ compared to the control. ${ }^{* * *} p<0.001$.

showed no effect of CsA on the expression of Tlr2, Tlr3, Tlr5, and Tlr9 in mpkCCD $\mathrm{cl}_{4}$ cells, as well as on the expression of Tlr2, Tlr3, and Tlr9 in RAW 264.7 cells (data not shown). TLR-mediated recognition of bacterial components induces a cascade of signaling events that finally leads to the activation of the transcriptional factor NF- $\kappa B$ and MAP kinases, which are critical in the regulation of genes involved in inflammation [26]. Western blot analyses were performed to check the TLR4 expression and the results showed that CsA induces a downregulation of TLR4 protein level in a dose-dependent manner, specifically in renal epithelial mpkCCD $\mathrm{cl}_{4}$ cells (Fig. 1b). To identify the influence of CsA on LPS-induced cell activation, $\mathrm{mpkCCD}_{\mathrm{cl} 4}$ cells were then incubated without or with $10 \mathrm{ng} / \mathrm{mL}$ of LPS for $6 \mathrm{~h}$ after incubation with CsA $\left(10^{-8} \mathrm{M}\right)$ for $18 \mathrm{~h}$. LPS induced the phosphorylation of the 


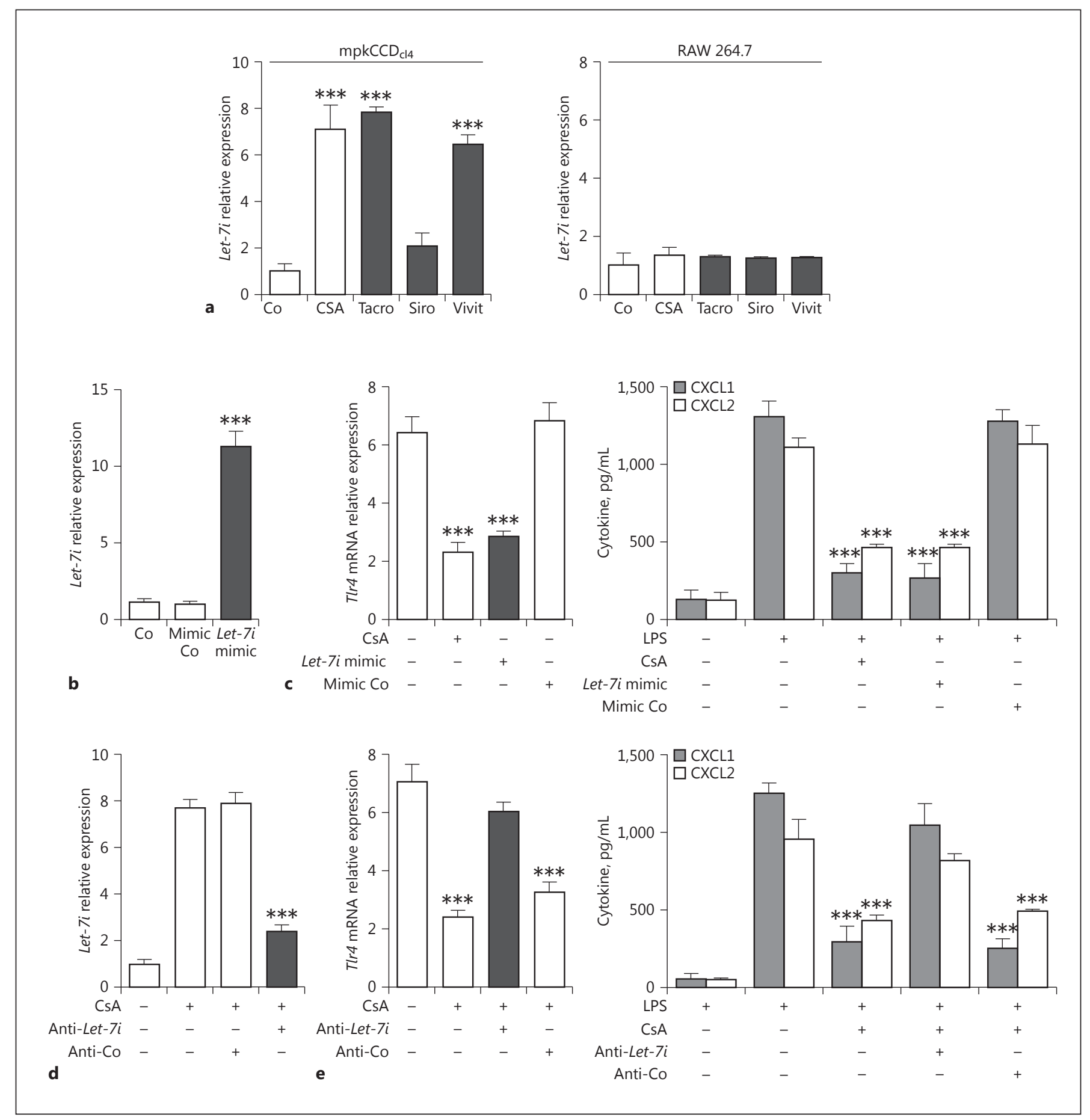

Fig. 3. CsA induces Let-7i expression targeting TLR4 in renal epithelial cells. a Quantitative RT-PCR expression analysis of Let-7i levels in mpkCCD $\mathrm{cl}_{4}$ and RAW264.7 cells treated with CsA, tacrolimus (Tacro), sirolimus (Siro), and 11R-Vivit (Vivit) for $18 \mathrm{~h}$ $\left(10^{-8} \mathrm{M}\right)$. b Let-7i expression in $\mathrm{mpkCCD}_{\mathrm{cl} 4}$ cells transfected with a Let-7i mimic or a mimic control (mimic Co). c Tlr4 mRNA relative expression and CXCL1 (grey bars) and CXCL2 (white bars) secretion measured by ELISA in mpkCCD $\mathrm{cl}_{4}$ cells transfected or not with a Let-7i mimic or mimic control, then treated or not with CsA for
$18 \mathrm{~h}$, and then stimulated (right panel) or not (left panel) with LPS for 6 h. $\mathbf{d}$ Let-7i expression in mpkCCD $_{\mathrm{cl} 4}$ cells transfected with an anti-Let-7i or an anti-miR control (anti-Co) after stimulation with CsA. e Tlr 4 mRNA relative expression and CXCL1 (grey bars) and CXCL2 (white bars) secretion measured by ELISA in mpkCCD ${ }_{\mathrm{cl}}$ cells transfected or not with an anti-Let-7i or anti-miRNA control (anti-Co), then treated or not with CsA for $18 \mathrm{~h}$, and stimulated (right panel) or not (left panel) with LPS for $6 \mathrm{~h}$. Values are presented as the mean \pm SE compared to the control. ${ }^{* * *} p<0.001$. 
NF- $\kappa B$ subunit p65 as well as of the MAP kinases extracellular signal-regulated kinase (ERK) $1 / 2$ and JNK (Fig. 1c). However, with the preincubation with CsA, their activation was impaired (Fig. 1c; online suppl. Fig. 1b). We then analysed the LPS-induced secretion of the chemokine Cxcl-2 by ELISA. We checked that Cxcl-2 secretion was TLR4 dependant in mpkCCD cl4 $_{4}$ cells (online suppl. Fig. 1c), in MCD cells (online suppl. Fig. 1d), in RAW 264.7 cells (online suppl. Fig. 1e), as well as in BMMs (online suppl. Fig. 1f) by using siRNA targeting TLR4 on LPS-treated cells. Cxcl-2 has been shown to be secreted by renal epithelial cells after TLR 4 activation by UPEC and transcriptionally regulated by NF- $\kappa \mathrm{B}[11,27]$. The results showed that LPS induces $\mathrm{Cxcl} 2$ secretion in mpkCCD ${ }_{\mathrm{cl} 4}$ cells, RAW 264.7 cells, primary cultures of MCD cells, as well as in BMMs. Preincubation with CsA induces a decrease of $\mathrm{Cxcl} 2$ secretion only in $\mathrm{mpkCCD} \mathrm{Cl}_{4}$ cells and in primary cultures of MCD cells in a dose-dependent manner. These results indicate that CsA inhibits LPS-induced cell activation specifically in MCD cells by decreasing the Tlr4 mRNA expression.

\section{CsA Decreases Tlr4 Expression through a miR-}

Dependent Process in Renal Collecting Duct Cells

miRs can modulate the expression of mRNAs and therefore decrease the expression of key proteins involved in major signaling pathways [18-21]. To check whether the downregulation of Tlr4 expression in collecting duct cells by CsA is induced by the presence of miRs, we depleted the whole miRs from the cells before incubation with LPS. In the canonical pathway of miRs biogenesis, the transcript (primary precursor, pri-miR) forms a microprocessor complex with the RNase III enzyme Drosha and the dsRNA-binding protein DGCR8/ Pasha in the nucleus [28]. The pri-miR was then cut in an approximate 70-nucleotide precursor hairpin (pre$\mathrm{miR}$ ), which is translocated to the cytoplasm by Exportin-5. In the cytoplasm, pre-miRs were processed to an approximate 21-nucleotide $\mathrm{miR} / \mathrm{miR}$ duplex by a complex formed by the RNase III enzyme Dicer and TRBP/ PACT/Loqs. One strand of the duplex was loaded onto Argonaute proteins and incorporated into the miRinduced silencing complex, miRISC, whereas the other strand was released and degraded. To transiently deplete mature miRs from the mpkCCD $\mathrm{cl}_{4}$ cells, we transfected them with a silencing RNA against Drosha or Dicer before the incubation with CsA, and then measured the Tlr 4 mRNA expression by quantitative PCR. The results showed that the CsA-induced decrease of Tlr4 mRNA expression was antagonised when silencing either Dro- sha or Dicer, the 2 major enzymes allowing miR maturation (Fig. 2a). This result suggests that the downregulation of the expression of Tlr4 mRNA caused by CsA occurs through a mechanism involving miRs. We then stimulated the cells with LPS after the silencing of Drosha or Dicer and the preincubation with CsA to check the levels of Cxcl1 and Cxcl2 secretion (Fig. 2b). The results showed that cytokine secretion was restored when the cells were depleted of mature miRs, showing that the absence of mature miRs allows the activation of the collecting duct cells by LPS in the presence of CsA. To identify which $\mathrm{miR}$ could be involved in this regulation, we performed an miR PCR array assay on mpkCCD $\mathrm{cl}_{4}$ cells in cubated or not with CsA (Fig. 2c). After the data analysis, we could identify miRs specifically modulated in the presence of CsA. Among them, Let-7i could be possibly involved in the regulation of the Tlr4 gene. Therefore, mpkCCD ${ }_{\mathrm{cl} 4}$ cells and RAW 264.7 cells were incubated with CsA and checked for the expression of Let-7i. The results showed that Let-7i was induced in renal collecting duct cells, but not in macrophages, in the presence of CsA (Fig. 2d). Overall, these results suggest that CsA induces Let-7i specifically in renal collecting duct cells, and that this miR might be responsible for the downregulation of Tlr4 mRNA expression and the subsequent inhibition of LPS-induced cell activation.

\section{CsA Induces Let-7i Expression Targeting TLR4 in Renal Collecting Duct Cells}

CsA forms a complex with cyclophilin, blocking the calcineurin-calmodulin-induced phosphorylation of nuclear factor of activated T cells (NFAT) transcription factor for IL-2 production. Similarly to CsA, tacrolimus (also known as FK506) is another macrolide antibiotic used as an immunosuppressive agent that interferes with

Fig. 4. CsA impairs the host defence during UTI by decreasing the expression of TLR4 in epithelial cells. a Bacterial load in kidneys of $L p s^{n}$ and $L p s^{d}$ mice treated with CsA ( $5 \mathrm{mg} / \mathrm{kg}$ ) or its vehicle for 5 days and $24 \mathrm{~h}$ after UPEC infection. b Illustrations of nodular infiltrates in fixed day-3 postinfected kidneys. Scale bars, $50 \mu \mathrm{m}$. MPO activity (c) and CXCL1 and CXCL2 (d) secretion in the $24 \mathrm{~h}$ postinfected kidneys from vehicle-treated and CsA-treated $L p s^{n}$ or $L p s^{d}$ mice. e Let-7i, Tlr4, Cxcl1, and Cxcl2 mRNA expression analyses measured by quantitative real-time PCR in kidneys from vehicle-treated and CsA-treated $L p s^{n}$ or $L p s^{d}$ mice after UPEC inoculation. f Relative expression of Let-7i, Tlr4, Cxcl1, and Cxcl2 mRNAs measured by quantitative real-time PCR in confluent cultures of $L p s^{n}$ or $L p s^{d}$ MCD cells incubated with vehicle or CsA for $18 \mathrm{~h}$ and compared to untreated MCD cells. Values are presented as the mean \pm SE compared to the control. ${ }^{* * *} p<0.001$.

(For figure see next page.) 

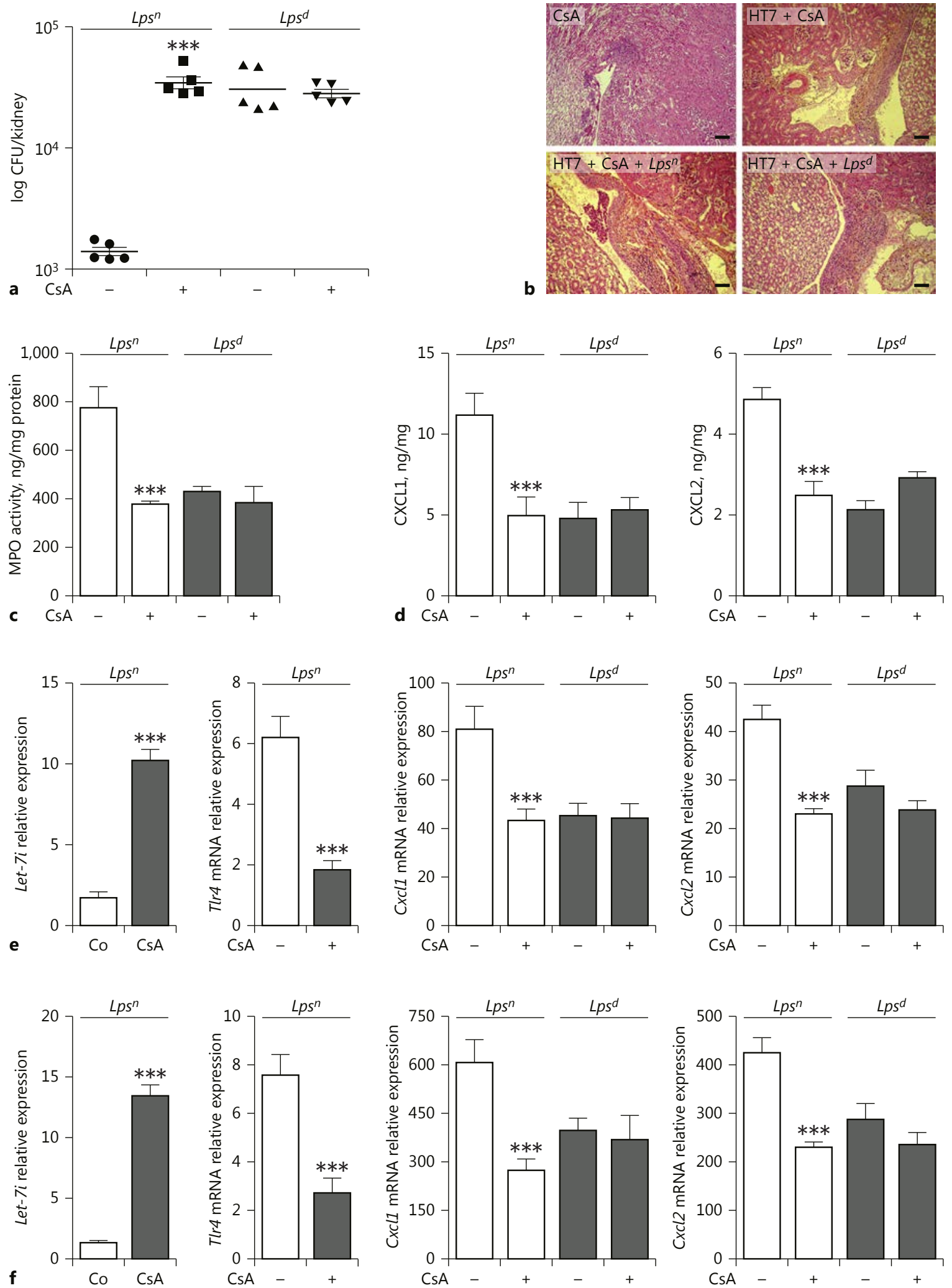
the intracytoplasmic calcineurin system to inhibit NFAT [29]. On the other hand, sirolimus (also known as rapamycin) is a macrocyclic lactone also used as an immunosuppressive agent although it acts differently to the other 2. Even though it structurally resembles tacrolimus and binds to the same intracellular protein immunophilin, it blocks the activation of $\mathrm{mTOR}$, a serine protein kinase important for cell cycle progression [30]. mpkCCD ${ }_{\text {cl } 4}$ cells and RAW 264.7 cells were incubated with CsA, tacrolimus, sirolimus, and 11R-Vivit, a cellpermeable peptide that specifically inhibits the interaction of calcineurin-NFATs without affecting calcineurin phosphatase activity [31]. The results showed that CsA and tacrolimus induce Let-7i expression in $\mathrm{mpkCCD}_{\mathrm{cl} 4}$ cells but not in RAW 264.7 cells (Fig. 3a). However, incubation with sirolimus did not induce Let-7i expression, neither in mpkCCD $\mathrm{cl}_{4}$ cells nor in RAW 264.7 cells. Incubation with 11R-Vivit had the same effect as CsA and tacrolimus, inducing the expression of Let-7i specifically in mpkCCD ${ }_{\mathrm{cl} 4}$ cells (Fig. 1a). These results indicate that calcineurin inhibitors induce Let-7i expression in renal collecting duct cells. The Let-7 family, and especially Let-7i, has already been shown to interfere with TLR4 signaling in human biliary epithelial cells during Cryptosporidium parvum infection [32]. Functional studies in renal collecting duct cells were performed to link TLR4 and Let-7i in our infection model. $\mathrm{mpkCCD}_{\mathrm{cl} 4}$ cells were transfected with a synthetic Let-7i mimic or a mimic control and then incubated or not with CsA. The presence of Let7-i after Let-7i mimic transfection in mpkCCD $\mathrm{cl}_{4}$ cells was checked by quantitative PCR (Fig. 3b). In the presence of CsA alone, Tlr4 expression was downregulated and the same effect could be observed in $\mathrm{mpkCCD}_{\mathrm{cl} 4}$ transfected with the Let-7i mimic in the absence of CsA (Fig. 3c, left panel). After LPS stimulation, Cxcl1 and Cxcl2 secretion were assessed by ELISA (Fig. 3b). In the presence of CsA and LPS, cytokine secretion was impaired in $\mathrm{mpkCCD}_{\mathrm{cl} 4}$ cells. In the same way, cytokine secretion was also impaired in the presence of LPS and in the absence of CsA in mpkCCD cl4 $_{4}$ cells transfected with the Let-7i mimic. On the other hand, we used an anti-Let-7i mimic to inhibit the expression of Let-7i during CsA incubation. We checked the inhibition of the expression of Let-7i in the presence of CsA by quantitative PCR (Fig. 3d). Tlr4 expression decreased in the presence of CsA, but was restored in the presence of anti-Let-7i and CsA (Fig. 3e, left panel). Similarly, in the presence of LPS, Cxcl1, and Cxcl2, secretion was inhibited in the presence of CsA and restored in the presence of an anti-Let-7i and CsA together (Fig. 3e, right panel).
Since we previously showed that CsA impairs Nod1 expression in renal tubular cells infected with UPEC [16], we checked that Let-7i had no effect on Nod1 expression (online suppl. Fig. 2). Altogether, these results suggest that CsA induces the miR Let-7i in renal collecting duct cell, which in turn downregulates the expression of Tlr4 and downstream signaling.

\section{CsA-Induced Inhibition of the TLR4-Mediated}

Innate Host Defense in Response to UPEC Leads to

Exacerbated Kidney Infection in vivo

The results from the in vitro studies indicated that CsA acts as a potent inhibitor of TLR4-mediated innate immunity. However, the inhibitory mechanism(s) of the calcineurin inhibitor on the innate immune response are still debated. Recently, we have shown that CsA decreases renal susceptibility to UPEC through an NFATc1dependent ignition of Nod1, which is involved in the recruitment of phagocytic cells to the site of inflammation $[16,17]$. Because TLR4 has been shown to also play a key role in renal host defense against pyelonephritic-associated UPEC, the question arises as to whether CsA also impairs the TLR4-mediated immune response during UTI. To answer this question, adult female $\mathrm{C} 3 \mathrm{H} / \mathrm{HeN}$ $L p s^{n}$ mice and $\mathrm{C} 3 \mathrm{H} / \mathrm{HeJ} L p s^{d}$ mice (8 mice per group) were left untreated or received a daily subcutaneous injection of CsA $(5 \mathrm{mg} / \mathrm{kg})$ diluted in endotoxin-free castor oil for 5 days before the infection experiments. As controls, $\mathrm{C} 3 \mathrm{H} / \mathrm{HeN} L p s^{n}$ mice received a subcutaneous injection of castor oil alone for 5 days. The mice were given an intraurethral injection of UPEC. Thereafter, bacterial loads in the kidney, histology, MPO activity, Cxcl1 and Cxcl2 expression and secretion, as well as TLR4 expres-

Fig. 5. Treatment with a synthetic Let-7i mimics the effects of CsA in kidneys colonised by UPEC. a Bacterial load in $24 \mathrm{~h}$ postinfected kidneys of wild-type mice treated with CsA ( $5 \mathrm{mg} / \mathrm{kg}$ ) for 5 days or with a synthetic Let-7i mimic (mimic miRNA) intraperitoneally injected ( $2 \mathrm{nmol} / \mathrm{mice}$ ) just before UPEC (HT7) infection. b Illustrations of nodular infiltrates in fixed day-3 postinfected kidneys from wild-type mice treated with CsA ( $5 \mathrm{mg} / \mathrm{kg}$ ) for 5 days or with a mimic miRNA intraperitoneally injected ( $2 \mathrm{nmol} / \mathrm{mice})$ just before the HT7 infection. Scale bars, $50 \mu \mathrm{m}$. c MPO activity in the $24 \mathrm{~h}$ postinfected kidney homogenates from wild-type mice treated with CsA or mimic miRNA. d Production of CXCL1 and CXCL2 in the $24 \mathrm{~h}$ postinfected kidneys from mimic miRNAtreated or CsA-treated wild-type mice. e Relative expression of Let-7i, Tlr4, Cxcl1, and Cxcl2 mRNAs measured by quantitative real-time PCR in kidneys from wild-type mice treated or not with the Let-7i mimic miRNA, and stimulated or not with CsA for 5 days before the infection by HT7. Values are presented as the mean \pm SE compared to the control. ${ }^{* * *} p<0.001$.

(For figure see next page.) 


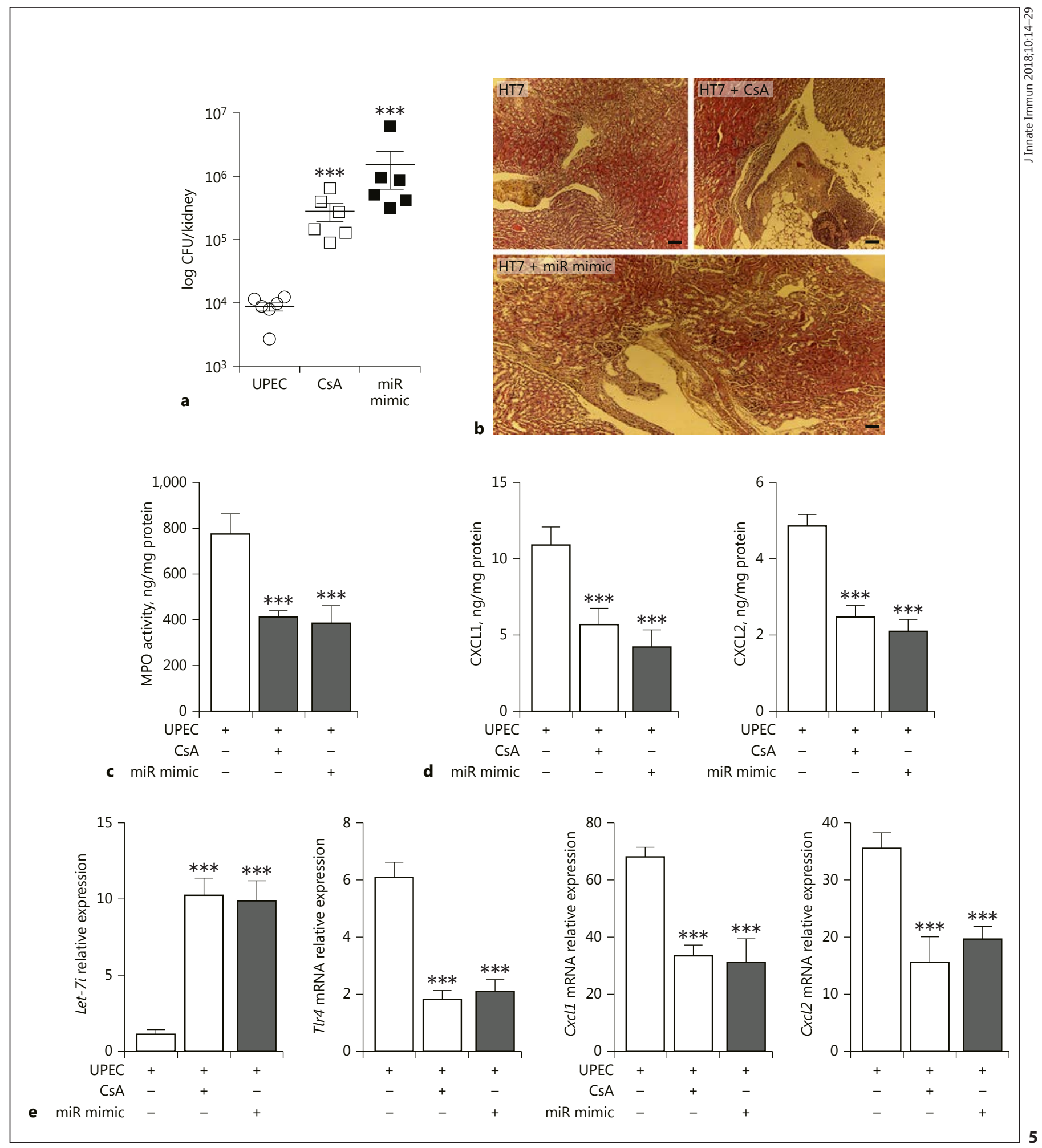

Let-7i Controls the TLR4-Mediated

J Innate Immun 2018;10:14-29 
sion were analysed $24 \mathrm{~h}$ after the transurethral inoculation of the UPEC strain HT7 [33]. $L p s^{d}$ mice were more susceptible to infection since the renal bacterial burden at $24 \mathrm{~h}$ after challenge was significantly greater than in kidneys from $L p s^{n}$ mice (Fig. 4a). In the presence of CsA, the bacterial load in the kidneys of $L p s^{n}$ mice was dramatically increased, but no effect was had on the bacterial load in the kidneys of $L p s^{d}$ mice. The same tendency was observed in the bladder of the infected mice (online suppl. Fig. 3). These results suggest that CsA favours bacterial proliferation in the kidneys though a process involving TLR4. Infiltrating cells surrounding tubules, including MCDs, as well as damage in the kidneys were detected in $L p s^{n}$ mice and increased when they were treated with CsA, and also to a lower extent in $L p s^{d}$ kidneys colonised with UPEC (Fig. 4b). Neutrophil migration was assessed by measuring MPO activity in renal homogenates. As previously reported, MPO activity was lower in $L p s^{d}$ than in $L p s^{n}$ kidneys colonised by UPEC (Fig. 4c). CsA treatment caused a marked decrease in MPO activity in the kidneys of UPEC-infected $L p s^{n}$ mice as compared to non-CsA-treated infected $L p s^{n}$ mice (Fig. 4c). CsA treatment had no effect on MPO activity from the kidneys of UPEC-infected $L p s^{d}$ mice. Chemoattractant chemokines, such as $\mathrm{Cxcl} 1$ (KC) and $\mathrm{Cxcl} 2$ (MIP-2), play a key role in the migration of PMNs to mucosal sites of inflammation to produce efficient bacterial clearance $[11,16]$. Cxcl1 and $\mathrm{Cxcl} 2$ secretion was assessed by ELISA in the kidney. Consistent with these findings, the production of $\mathrm{Cxcl} 1$ and $\mathrm{Cxcl} 2$, the 2 main neutrophil chemoattractant chemokines, was significantly lower in the infected kidneys of $L p s^{n}$ mice pretreated with CsA than in those of untreated mice (Fig. 4d). The effects of CsA appeared to be related to the alteration of TLR4 signaling, since the $\mathrm{Cxcl} 1$ and $\mathrm{Cxcl} 2$ protein levels measured in the infected $L p s^{d}$ kidneys, which were significantly lower than in those of infected $L p s^{n}$ kidneys, were not affected by the CsA treatment (Fig. 4d). The relative expression of Let-7i and Tlr4 mRNA was assessed by quantitative PCR in the whole kidney (Fig. 4e, left and central panels) and in microdissected MCD cells isolated from kidneys after CsA treatment (Fig. 4f, left and central panels). Consistent with our in vitro data, whereas Let-7i expression was increased, Tlr4 mRNA expression was inversely decreased in the whole kidney, and especially in MCD cells. The relative levels of Cxcl1 and $\mathrm{Cxcl} 2 \mathrm{mRNA}$ expression after CsA treatment and/or UPEC infection was also measured in the whole kidney (Fig. 4e, right panel) and in MCD cells microdissected after infection (Fig. 4f, right panel). Administration of
CsA for 5 days before infection induced a significant decrease in Cxcl1 and Cxcl2 mRNA expression in the whole kidney of $L p s^{n}$ mice, as well as in MCD cells. Cxcll and Cxcl2 mRNA expression was decreased in the whole kidney and the MCD of infected $L p s^{d}$ mice compared to infected $L p s^{n}$ mice, but the treatment with CsA did not have any effect. These findings demonstrate that CsA influences inflammatory responses in vivo, and further suggest that the suppressor effect of CsA is mainly restricted to TLR4-dependent immune activation.

\section{Administration of a Synthetic Let-7i Mimics the}

Deleterious Effects of CsA on Renal Bacterial Defense

In order to analyse the effect of in vivo administration of a synthetic Let-7i mimic, wild-type mice were left untreated or received a daily subcutaneous injection of CsA $(5 \mathrm{mg} / \mathrm{kg}$ ) diluted in endotoxin-free castor oil for 5 days before infection experiments. Before the infection with UPEC, a group of mice untreated with CsA received an intraperitoneal injection of $2 \mathrm{nmol}$ of Let-7i mimic per mouse. We checked the presence of the Let-7i mimics by quantitative PCR and FACS on microdissected MCD cells from the tubules of the injected mice, as previously shown [34]. At $24 \mathrm{~h}$ after infection, the bacterial load in the kidneys of mice treated with CsA was increased compared to CsA-untreated mice (Fig. 5a). Interestingly, the bacterial load in the kidneys of infected mice treated with the Let-7i mimic exhibited an equivalent increase to the CsA-treated mice (Fig. 5a). The same results were observed in the bladder of infected mice (online suppl. Fig. 4). Similar results were also observed for kidney damage (Fig. 5b), MPO activity (Fig. 5c), and CXCL1 and CXCL2 secretion in the kidney (Fig. 5d). As a control, the level of Let-7i expression in the kidney of the

Fig. 6. Treatment with an anti-Let-7i antagonises the effects of CsA in kidneys colonised by UPEC. a Bacterial load in $24 \mathrm{~h}$ postinfected kidneys of wild-type mice treated or not with CsA $(5 \mathrm{mg} / \mathrm{kg})$ for 5 days or with an anti-Let-7i intraperitoneally injected $(2 \mathrm{nmol} /$ mice) just before the UPEC (HT7) infection. b Illustrations of nodular infiltrates in fixed day-3 postinfected kidneys from wild-type mice treated with CsA $(5 \mathrm{mg} / \mathrm{kg})$ for 5 days or with an anti-Let-7i intraperitoneally injected ( $2 \mathrm{nmol} / \mathrm{mice}$ ) just before the HT7 infection. Scale bars, $50 \mu \mathrm{m}$. c MPO activity in the $24 \mathrm{~h}$ postinfected kidney homogenates from wild-type mice with CsA or anti-Let-7i treatment. d Production of CXCL1 and CXCL2 in the $24 \mathrm{~h}$ postinfected kidneys from anti-Let-7i-treated and CsA-treated wild-type mice. e Relative expression of Let-7i, Tlr4, Cxcl1, and Cxcl2 mRNAs measured by quantitative real-time PCR in kidneys from wild-type mice treated or not with an anti-Let-7i, and stimulated or not with CsA for 5 days before the infection by HT7. Values are presented as the mean \pm SE compared to the control. ${ }^{* *} p<0.01,{ }^{* * *} p<0.001$.

(For figure see next page.) 


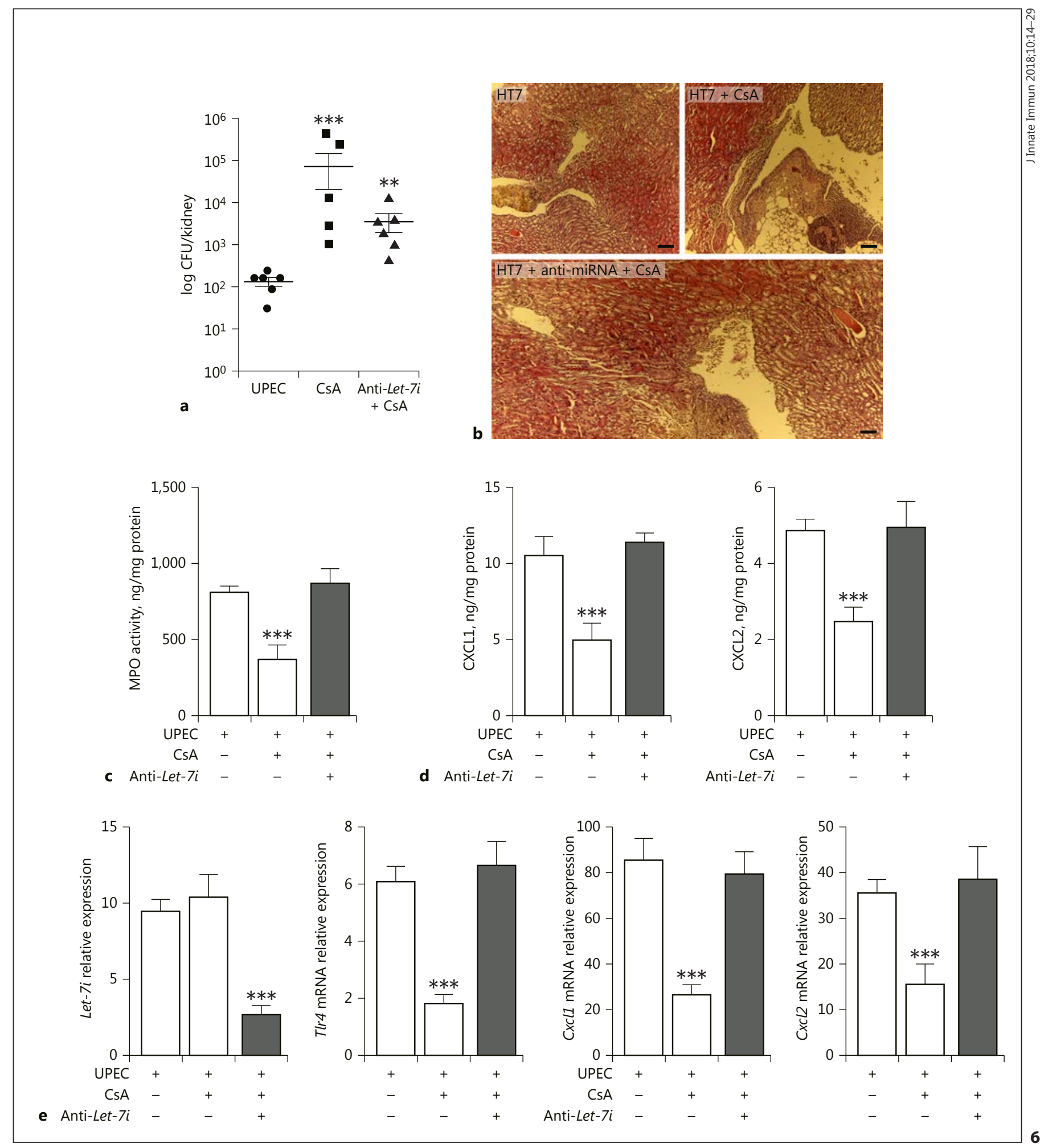

Let-7i Controls the TLR4-Mediated

J Innate Immun 2018;10:14-29 
UPEC-infected mice pretreated with the mimic was checked (Fig. 5e, left panel). The consequences of the injection of the Let-7i mimic on Tlr4 and Cxcl1 and Cxcl2 mRNA expression were then analysed. The results showed that Let-7i mimic considerably decreased the expression of Tlr4, Cxcl1, and Cxcl2 to almost the same extend as CsA treatment does (Fig. 5e, central and right panels). Overall, the results showed that the injection of Let-7i mimics the effects of CsA in renal epithelial cells during UPEC infection by decreasing Tlr4 expression, Cxcl1 and Cxcl2 expression and protein secretion, and MPO activity, and increases the UPEC bacterial load and kidney damage.

\section{An Anti-Let-7i Antagonises the Inhibitory Action of CsA in Kidneys during UPEC Infection}

The effects of an injection of an anti-Let-7i were analysed in mice treated with CsA. Wild-type mice were left untreated or received a daily subcutaneous injection of CsA $(5 \mathrm{mg} / \mathrm{kg}$ ) diluted in endotoxin-free castor oil for 5 days before infection experiments. Before the infection with UPEC, a group of mice treated with CsA received an intraperitoneal injection of $2 \mathrm{nmol}$ of anti-Let-7i per mouse. The results showed that $24 \mathrm{~h}$ after infection, the bacterial load in the kidneys of CsA-treated mice increased compared to non-treated mice, but interestingly the additional injection of an anti-Let-7i decreased the bacterial load compared to mice only treated with CsA (Fig. 6a). The same results were observed in the bladder of the infected mice (online suppl. Fig. 5). Histological studies showed that the injection of an anti-Let-7i protects against the deleterious effects of CsA during UPEC infection by reducing tissue damage (Fig. 6b). Moreover, the injection of an anti-Let-7i restored the MPO activity inhibited by CsA (Fig. 6c), as well as the secretion of CXCL1 and CXCL2 (Fig. 6d). As a control, we checked the expression of Let-7i in the kidney of mice treated with CsA and injected with the anti-Let-7i. The results showed a decrease of the expression compared to the mice treated with CsA only (Fig. 6e, left panel). The consequences of the injection of the anti-Let-7i on Tlr4, Cxcl1, and Cxcl2 mRNA expression were analysed. The results showed that the anti-Let-7i restored the expression of Tlr4, Cxcll, and $\mathrm{Cxcl} 2$ when mice were treated with CsA (Fig. 6e, central and right panels). Overall, the results showed that the injection of an anti-Let-7i mimic reverses the effects of CsA in renal epithelial cells during UPEC infection by restoring Tlr4 expression, $\mathrm{Cxcl} 1$ and $\mathrm{Cxcl} 2$ expression and protein secretion, and MPO activity, and favours the decrease of UPEC bacterial load and kidney damage.

\section{Discussion}

We analysed the effects of CsA, a potent immunosuppressant that has wide clinical applications for autoimmune disorders and the prevention of rejection in organ transplantation, on the activation of collecting duct cells that represent the preferential site of adhesion and translocation of ascending UPEC during kidney infections. CsA induced the concentration-dependent inhibition of LPS-stimulated proinflammatory mediators in collecting duct cells. This effect appears to be related to TLR4 downregulation by the induction of an $\mathrm{miR}$, Let-7i, due to the presence of CsA. Several studies already showed that CsA can specifically induce miRs in different cell types, such as cardiomyocytes, glioma cells, and renal tubular epithelial cells [34-37]. CsA binds to cyclophilin and the cyclophilin-CsA complex will then bind to calcineurin, a protein phosphatase $2 \mathrm{~B}, \mathrm{PP} 2 \mathrm{~B}$, and inhibit IL-2 synthesis, and thereby T-cell functions. However, CsA may have adverse actions and induce tubulointerstitial nephropathy, which could impair the function of renal grafts [38]. Several studies have shown that CsA may induce the apoptosis of renal tubule epithelial cells $[14,39]$. These results suggest that CsA may act as a potent cellular stress inducer. However, the effects of CsA on the activation of the different cellular pathways leading to cell survival or apoptosis are still not well known. Prolonged immunosuppression favours the occurrence of UTI and acute pyelonephritis in kidney-transplanted patients. Although UPEC adhering to renal collecting duct cells trigger a solid inflammatory response for the defense of the host, the effects of CsA on immune response capacities resulting from the cellular activation and their consequences on renal bacterial invasion still remain poorly understood. It has already been shown that miR-494 promotes cyclosporine-induced nephrotoxicity in the kidney and epithelial to mesenchymal transition by inhibiting PTEN [35]. Also, CsA induces cardiomyocyte apoptosis through the miR-377-XIAP/NRP2 axis [37]. We demonstrated here, for the first time, the modulation of specific miR by CsA, involved in the regulation of the inflammation, and their direct effects on TLR signaling.

The mechanisms involved in the induction of the expression of miR induced by CsA seem to be related to the activation and the translocation of NFAT, as well as the activation of PKC. The use of a PKC inhibitor alone was able to restore the inflammatory response against UPEC. It has already been shown that CsA and the PKC inhibitor GF10923X antagonise the effects of the miR-19 family, regulating phenotypes of cardiomyocytes via the suppres- 
sion of multiple direct target genes [40]. Moreover, several signaling pathways activated during UPEC infection, including the pathways known to activate the innate immune response, interact with calcium-dependent signaling pathways. Interestingly, expression of IL- 8 has been shown to be under the control of artificially induced $\mathrm{Ca}^{2+}$ oscillations due to the frequency-modulated expression of the transcription factor NF- $\kappa B$ [41]. Altogether, these finding suggest that $\mathrm{CsA}$ induces the transcription of specific miRs through a mechanism dependent of PKC and NFAT, leading to the modulation of the immune response against UPEC.

Analysis of the innate immune response using an experimental model of ascending UTI revealed that the pretreatment of mice with CsA prior to the transurethral inoculation of UPEC induced a marked fall in the cytokine production by epithelial cells as well as in neutrophil recruitment. A dramatic rise in the renal bacterial burden in the infected kidneys of TLR4-expressing $\mathrm{C} 3 \mathrm{H} / \mathrm{HeN}$ mice, but not in infected TLR4-defective $\mathrm{C} 3 \mathrm{H} / \mathrm{HeJ}$ mice kidneys, was also shown. The same effect was observed in CsA-treated $\mathrm{C} 3 \mathrm{H} / \mathrm{HeN}$-infected kidneys, where the expression of Let-7i was increased. Treatment with a synthetic Let-7i mimic reproduced the effects of CsA. Conversely, treatment with an anti-Let-7i antagonised the effects of CsA and rescued the innate immune response of collecting duct cells against UPEC. It was previously shown that Let-7 family members can modulate TLR4 signaling. Let-7i regulates TLR4 expression in cholangiocytes and contributes to epithelial immune responses against C. parvum infection [34]. Another study showed that the expression of Let-7i is associated with the TLR4 signal in coronary artery disease, and statins downregulate the signal via Let-7i expression in these patients [42]. Overall, these results showed that Let-7i is able to directly target the innate immune receptor TLR4 and to quickly modulate the innate immunity against bacteria. Targeting Let-7i seems to be a good way to activate or inhibit the inflammation to favour the resolution of the infection.

UTIs and acute pyelonephritis are the most frequent infectious complications occurring after renal graft. They frequently occur immediately after surgery and are generally considered a consequence of a direct exposure to pathogens favoured by the insertion of an intraurethral stent and urethral catheters. Although antibiotic prophylactic treatments and progress in surgical procedures have reduced the frequency of immediate postoperative UTIs, their frequency still remains higher in the population of kidney-transplanted patients than in the normal

Let-7i Controls the TLR4-Mediated

Immune Response population. Until recently, the impact of acute pyelonephritis on renal graft survival as well as renal graft function has been neglected. A retrospective study on a large cohort of transplanted patients (approx. 29,000 patients) revealed that late UTI occurring after the first post-transplant year represented a risk factor for renal graft dysfunction [3]. We also showed that acute pyelonephritis represents a risk factor, independent of rejection episodes, impairing the long-term kidney graft function [6].

During bacterial invasion, PMNs attracted to the site of infection by chemoattractant chemokines (mainly IL- 8 in humans) play key roles in the renal clearance of bacteria [43]. We found that CsA, in addition to its inhibitory action on the TLR4-mediated production of chemoattractant chemokines, also inhibited the expression of nucleotide-binding oligomerisation domain 1 (Nod1), an intracellular receptor involved in the innate immune response against bacteria, in phagocytic PMNs [16]. A primary or acquired deficit in pattern recognition molecules from activated signaling pathways involved in the migration of PMNs to the site of inflammation to kill bacteria leads to functional alterations of PMNs, thus favouring bacterial infections and increasing the susceptibility of the host to repeated infections $[16,44,45]$. This scenario is quite frequently encountered in transplanted patients, who often exhibit recurrent UTI and acute pyelonephritis (representing more than $15 \%$ of patients with UTI) under prolonged immunosuppressive treatment [6]. Altogether, these results highlight the inhibitory effect of CsA on the innate immune response, and particularly on the direct effect of CsA on the expression of innate immune receptors.

This study has provided new insights in the understanding of the inflammatory response from injured kidneys colonised by UPEC. In particular, the experiments proposed should further assess the critical role of epithelial renal cells in the recognition of uropathogenic bacteria and their participation, additional to bone marrowderived cells, in the initiation of a solid immune response for the defense of the host. The demonstration of the mechanism of action of immunosuppressive agents on the inhibition of the inflammatory pathway in target renal epithelial cells is novel and has pathophysiological implications. miRs might be of clinical use in the treatment of infections of the urinary tract and kidneys, especially in transplanted patients, even though the direct effects on allograft rejection has to be checked. A better understanding of the dysregulatory mechanisms of host defense against pathogens evidenced in kidney-transplanted patients is also important and has direct medical implications. The prevention of early UTI and acute py- 
elonephritis will certainly permit a prolonged preservation of the renal graft function. Clear identification of dysregulation of some of the immune receptors in blood samples from transplanted patients should also provide the basis for simple tests to control the capacities of immune responses of kidney-transplanted patients subjected to UTIs.

\section{Acknowledgements}

This work was funded by INSERM. ATIP-AVENIR funding was provided to Cécilia Chassin. We thank Dr. Loredana Saveanu (CRI, INSERM U1149) for her support.

\section{Disclosure Statement}

The authors declare no conflicts of interest.

\section{References}

1 de Souza RM, Olsburgh J: Urinary tract infection in the renal transplant patient. Nat Clin Pract Nephrol 2008;4:252-264.

2 Schmaldienst S, Dittrich E, Hörl WH: Urinary tract infections after renal transplantation. Curr Opin Urol 2002;12:125-130.

3 Abbott KC, Cruess DF, Agodoa LY, Sawyers ES, Tveit DP: Early renal insufficiency and late venous thromboembolism after renal transplantation in the United States. Am J Kidney Dis 2004;43:120-130.

4 Johnson JR, Russo TA: Molecular epidemiology of extraintestinal pathogenic (uropathogenic) Escherichia coli. Int J Med Microbiol 2005;295:383-404.

5 Alangaden GJ, Thyagarajan R, Gruber SA, Morawski K, Garnick J, El-Amm JM, West MS, Sillix DH, Chandrasekar PH, Haririan A: Infectious complications after kidney transplantation: current epidemiology and associated risk factors. Clin Transplant 2006;20: 401-409.

6 Pellé G, Vimont S, Levy PP, Hertig A, Ouali N, Chassin C, Arlet G, Rondeau E, Vandewalle A: Acute pyelonephritis represents a risk factor impairing long-term kidney graft function. Am J Transplant 2007;7:899-907.

7 Hagberg L, Engberg I, Freter R, Lam J, Olling S, Svanborg Edén C: Ascending, unobstructed urinary tract infection in mice caused by pyelonephritogenic Escherichia coli of human origin. Infect Immun 1983;40:273-283.

8 Tsuboi N, Yoshikai Y, Matsuo S, Kikuchi T, Iwami K, Nagai Y, Takeuchi O, Akira S, Matsuguchi T: Roles of Toll-like receptors in $\mathrm{C}-\mathrm{C}$ chemokine production by renal tubular epithelial cells. J. Immunol 2002;169:20262033.

9 Schilling JD, Martin SM, Hung CS, Lorenz RG, Hultgren SJ: Toll-like receptor 4 on stromal and hematopoietic cells mediates innate resistance to uropathogenic Escherichia coli. Proc Natl Acad Sci USA 2003;100:4203-4208.

10 Patole PS, Schubert S, Hildinger K, Khandoga S, Khandoga A, Segerer S, Henger A, Kretzler M, Werner M, Krombach F, Schlöndorff D, Anders HJ: Toll-like receptor-4: renal cells and bone marrow cells signal for neutrophil recruitment during pyelonephritis. Kidney Int 2005;68:2582-2587.
11 Chassin C, Goujon JM, Darche S, du Merle L, Bens M, Cluzeaud F, Werts C, Ogier-Denis E, Le Bouguénec C, Buzoni-Gatel D, Vandewalle A: Renal collecting duct epithelial cells react to pyelonephritis-associated Escherichia coli by activating distinct TLR4-dependent and -independent inflammatory pathways. J Immunol 2006;177:4773-4784.

12 Chassin C, Vimont S, Cluzeaud F, Bens M, Goujon JM, Fernandez B, Hertig A, Rondeau E, Arlet G, Hornef MW, Vandewalle A: TLR4 facilitates translocation of bacteria across renal collecting duct cells. J Am Soc Nephrol 2008;19:2364-2374.

13 Fellström B: Cyclosporine nephrotoxicity. Transplant Proc 2004;36:220S-223S.

14 Justo P, Lorz C, Sanz A, Egido J, Ortiz A: Intracellular mechanisms of cyclosporin Ainduced tubular cell apoptosis. J Am Soc Nephrol 2003;14:3072-3080.

15 Doller A, El-Sayed A, Müller R, Gutwein P, Kurowski C, Pfeilschifter J, Eberhardt W: Molecular mechanisms of cyclosporin A inhibition of the cytokine-induced matrix metalloproteinase-9 in glomerular mesangial cells. J Am Soc Nephrol 2007;18:581-592.

16 Tourneur E, Ben Mkaddem S, Chassin C, Bens M, Goujon JM, Charles N, Pellefigues C, Aloulou M, Hertig A, Monteiro RC, Girardin SE, Philpott DJ, Rondeau E, Elbim C, Werts C, Vandewalle A: Cyclosporine A impairs nucleotide binding oligomerization domain (Nod1)-mediated innate antibacterial renal defenses in mice and human transplant recipients. PLoS Pathog 2013;9: e1003152.

17 Vandewalle A, Tourneur E, Bens M, Chassin C, Werts C: Calcineurin/NFAT signaling and innate host defence: a role for NOD1-mediated phagocytic functions. Cell Commun Signal 2014;12:8.

18 Baltimore D, Boldin MP, O’Connell RM, Rao DS, Taganov KD: MicroRNAs: new regulators of immune cell development and function. Nat Immunol 2008;9:839-845.

19 Sonkoly E, Pivarcsi A: microRNAs in inflammation. Int Rev Immunol 2009;28:535-561.

20 Liston A, Linterman M, Lu LF: MicroRNA in the adaptive immune system, in sickness and in health. J Clin Immunol 2010;30:339-346.
21 O'Connell RM, Rao DS, Chaudhuri AA, Baltimore D: Physiological and pathological roles for microRNAs in the immune system. Nat Rev Immunol 2010;10:111-122.

22 Bens M, Bogdanova A, Cluzeaud F, Miquerol L, Kerneis S, Kraehenbuhl JP, Kahn A, Pringault E, Vandewalle A: Transimmortalized mouse intestinal cells (m-ICc12) that maintain a crypt phenotype. Am J Physiol 1996; 270:C1666-C1674.

23 Chassin C, Hornef MW, Bens M, Lotz M, Goujon JM, Vimont S, Arlet G, Hertig A, Rondeau E, Vandewalle A: Hormonal control of the renal immune response and antibacterial host defense by arginine vasopressin. J Exp Med 2007;204:2837-2852.

24 Chassin C, Kocur M, Pott J, Duerr CU, Gütle D, Lotz M, Hornef MW: miR-146a mediates protective innate immune tolerance in the neonate intestine. Cell Host Microbe 2010;8: 358-368.

25 Van Huyen JP, Bens M, Teulon J, Vandewalle A: Vasopressin-stimulated chloride transport in transimmortalized mouse cell lines derived from the distal convoluted tubule and cortical and inner medullary collecting ducts. Nephrol Dial Transplant 2001;16:238-245.

26 Zhang G, Ghosh S: Toll-like receptor-mediated NF- $\kappa B$ activation: a phylogenetically conserved paradigm in innate immunity. J Clin Invest 2001;107:13-19.

27 Jung YJ, Lee AS, Nguyen-Thanh T, Kim D, Kang KP, Lee S, Park SK, Kim W: SIRT2 regulates LPS-induced renal tubular CXCL2 and CCL2 expression. J Am Soc Nephrol 2015;26: 1549-1560.

28 Kim VN, Han J, Siomi MC: Biogenesis of small RNAs in animals. Nat Rev Mol Cell Biol 2009;10:126-139.

29 Sawada S, Suzuki G, Kawase Y, Takaku F: Novel immunosuppressive agent, FK506: in vitro effects on the cloned $\mathrm{T}$ cell activation. J Immunol 1987;139:1797-1803.

30 Brattström C, Tydén G, Säwe J, Herlenius G, Claesson K, Groth CG: A randomized, double-blind, placebo-controlled study to determine safety, tolerance, and preliminary pharmacokinetics of ascending single doses of orally administered sirolimus (rapamycin) in stable renal transplant recipients. Transplant Proc 1996;28:985-986. 
31 Aramburu J, Yaffe MB, López-Rodríguez C, Cantley LC, Hogan PG, Rao A: Affinity-driven peptide selection of an NFAT inhibitor more selective than cyclosporin A. Science 1999;285:2129-2133.

32 Chen XM, Splinter PL, O'Hara SP, LaRusso NF: A cellular micro-RNA, let-7i, regulates Toll-like receptor 4 expression and contributes to cholangiocyte immune responses against Cryptosporidium parvum infection. J Biol Chem 2007;282:28929-28938.

33 Chassin C, Hornef MW, Bens M, Lotz M, Goujon JM, Vimont S, Arlet G, Hertig A, Rondeau E, Vandewalle A: Hormonal control of the renal immune response and antibacterial host defense by arginine vasopressin. J Exp Med 2007;204:2837-2852.

34 Chen J, Zmijewska A, Zhi D, Mannon RB: Cyclosporine-mediated allograft fibrosis is associated with micro-RNA-21 through AKT signaling. Transpl Int 2015;28:232-245.

35 Yuan J, Benway CJ, Bagley J, Iacomini J: MicroRNA-494 promotes cyclosporine-induced nephrotoxicity and epithelial to mesenchymal transition by inhibiting PTEN. J Am Transplant 2015;15:1682-1691.
36 Yilaz Susluer S, Biray Avci C, Dodurga Y, Ozlem Dogan Sigva Z, Oktar N, Gunduz C: Downregulation of miR-195 via cyclosporin A in human glioblastoma cells. J BUON 2015; 20:1337-1340.

37 Zhu XD, Chi JY, Liang HH, Huangfu LT, Guo ZD, Zou H, Yin XH: MicroRNA-377 mediates cardiomyocyte apoptosis induced by cyclosporin A. Can J Cardiol 2016;32:12491259.

38 Kopp JB, Klotman PE: Cellular and molecular mechanisms of cyclosporin nephrotoxicity. J Am Soc Nephrol 1990;1:162-179.

39 Hortelano S, Castilla M, Torres AM, Tejedor A, Boscá L: Potentiation by nitric oxide of cyclosporin A and FK506-induced apoptosis in renal proximal tubule cells. J Am Soc Nephrol 2000;11:2315-2323.

40 Song DW, Ryu JY, Kim JO, Kwon EJ, Kim DH: The miR-19a/b family positively regulates cardiomyocyte hypertrophy by targeting atrogin-1 and MuRF-1. Biochem J 2014;457: 151-162.
41 Dolmetsch RE, Lewis RS, Goodnow CC, Healy JI: Differential activation of transcription factors induced by $\mathrm{Ca}^{2+}$ response amplitude and duration. Nature 1997;386:855-858 (erratum in Nature 1997;388:308).

42 Satoh M, Tabuchi T, Minami Y, Takahashi Y, Itoh T, Nakamura M: Expression of let-7i is associated with Toll-like receptor 4 signal in coronary artery disease: effect of statins on let$7 i$ and Toll-like receptor 4 signal. Immunobiology 2012;217:533-539.

43 Frendéus B, Godaly G, Hang L, Karpman D, Lundstedt AC, Svanborg C: Interleukin 8 receptor deficiency confers susceptibility to acute experimental pyelonephritis and may have a human counterpart. J Exp Med 2000; 192:881-890.

44 Andrews T, Sullivan KE: Infections in patients with inherited defects in phagocytic function. Clin Microbiol Rev 2003;16:597621.

45 Picard C, Puel A, Bustamante J, Ku CL, Casanova JL: Primary immunodeficiencies associated with pneumococcal disease. Curr Opin Allergy Clin Immunol 2003;3:451-459. 